\title{
Era uma vez o "país da alegria": mídia, estados de ânimo e identidade nacional
}

\author{
João Freire Filho \\ Doutor, Universidade Federal do Rio de Janeiro \\ joaofreirefilho@gmail.com
}

\begin{abstract}
Resumo
A alegria se consolidou, a partir dos anos 1930, como um componente marcante da brasilidade, decantado em verso e prosa, enaltecido em relatos de viajantes saudosos e ressaltado em discursos políticos e publicitários. Trata-se de um elemento constitutivo da identidade, da imagem e da reputação da nossa nação. Escritores e jornalistas atuaram, de maneira decisiva, para notabilizar a visão estereotipada do Brasil como o "país da alegria". Agora, sob o impacto de recentes inovações tecnológicas, transformações sociais e acontecimentos políticos, são eles também que ajudam a promover uma reconsideração da nossa autoimagem. O objetivo deste artigo é, justamente, examinar as mudanças nas narrativas sobre a cultura nacional e o caráter brasileiro. Destaco, em particular, nos discursos e nas representações que a sociedade brasileira vem produzindo a respeito de si mesma, o reconhecimento público da presença do ressentimento em nossa história, nossas relações sociais e nossa vida política.
\end{abstract}

\section{Palavras-chave}

Alegria. Ressentimento. Mídia. Estereótipo. Identidade nacional.

Um país de povo alegre, festeiro, que dribla todas as dificuldades com o célebre jeitinho, um país feliz! E mais! Um povo que nunca enfrentou guerras, nem pestes, nem vulcões, nem terremotos, nem furacões, nem lutas fratricidas. E mais! Um povo que convive em amenidade e cortesia, um povo prestativo, de coração bondoso, em que todas as cores e raças se misturam livremente, pois desconhece o preconceito racial, visto que aqui o preconceito é econômico. E mais! Um povo de extraordinária musicalidade, capaz de, com instrumentos improvisados tais como caixas de fósforos, copos, pratos e latas velhas, fazer música que impressiona a qualquer estrangeiro... 
Os brasileiros são bons porque sabem fazer de cada momento da vida, até mesmo dos momentos de vicissitude, um espetáculo da alegria de viver, um exemplo é a nossa, dos brasileiros, música popular brasileira, a internacional MPB. A música popular brasileira é boa. Foram os brasileiros que fizeram a música popular brasileira. Os brasileiros são bons. Os brasileiros são bons porque superam todos os obstáculos de cabeça erguida, e cada obstáculo superado com empenho, com coerência é matéria-prima para novos desafios, que levam sempre os brasileiros, que são bons, um pouco mais adiante, porque todo dia nasce novo, em cada amanhecer.

André Sant'anna, $O$ brasileiro é bom de $O$ Brasil é bom (2014).

O estereótipo foi moldado a partir dos anos 1930: Brasil, país da alegria transbordante e envolvente. Não tardaria para que o slogan luminoso repercutisse no imaginário global. Crônicas, ficções, ensaios, reportagens e campanhas turísticas reprisam as evidências da fabulosa animação do nosso povo, apreciável inclusive nos núcleos sociais menos favorecidos. A alegria é tamanha e tão gratuita que se afigura, ao mesmo tempo, indubitável e inverossímil. "Não sei por que tanta alegria, se metade desse povo passa fome.", admirou-se um dos profetas da utopia tupiniquim (RIBEIRO, [1987] 2008, p. 21). 0 antropólogo ecoava o espanto de outros espectadores bem nutridos: "Se saúde, facilidade, bem-estar fosse deduzível da alegria, o proletário nordestino vivia no paraíso.", registrou o "turista aprendiz" Mario de Andrade, após visitar bairros populares de Natal. "A gente daqui é alegre e cantar canto como ela não sei que se cante. E não deduzo isso da época de festa em que não estou. 0 pessoal amanhece já na cantoria. E tudo é pretexto para cantar." (ANDRADE, [1929] 1976, p. 259).

Motivo de orgulho patriótico, a típica alegria dos brasileiros foi captada e cristalizada em um singelo conjunto de imagens, ritmos e símbolos: os saracoteios do samba na Sapucaí; as ruas ocupadas por foliões eufóricos e irreverentes; garis que removem os restos da festa, bailando felizes da vida; a descontração desnuda nas praias; o jeito lúdico de praticar e de apreciar o futebol; a forma risonha ou gaiata de aguentar o fardo de uma rotina de trabalhos estafantes e de direitos precários.

Afirmação destemida da vida em sua plenitude? Aceitação simplória do status quo? Extravasamento tumultuoso dos instintos? Deferência necessária às demandas voluptuosas do corpo? Ao longo do tempo, manifestações emblemáticas do nosso propalado "jeito alegre de viver" suscitaram sentimentos e julgamentos discrepantes, variando da reprovação moral à exaltação poética. Mesmo entre os entusiastas surgem controvérsias quanto ao perfil 
existencial e político da nossa alegria nativa. Sua índole conformista ou pueril foi salientada em muitas oportunidades:

Dizem que o carioca nada leva a sério. Vejo nisso uma virtude. A facilidade com que ele põe em circulação as pilhérias e os trocadilhos mais irreverentes, e transforma os acontecimentos mais importantes em motivo de troça, deveria ser até cultivada pelos governos, porque é graças a ela que o carioca é bem humorado e pouco inclinado a desordens. [...] Quem quer que tenha tido ocasião de observar um pouco mais longamente o operário carioca no trabalho terá a impressão de que ele está sempre brincando. Numa oficina de mecânica, ou numa tipográfica, ou numa obra em construção - a atitude do operário é sempre a mesma. Ele entremeia o trabalho com pilhérias aos companheiros. Há sempre um ambiente de jocosidade envolvendo o seu trabalho. E não creio que este sofra grandemente com isso... esse bom humor, que é o melhor antídoto das rebeldias sociais. (MEDEIROS, [1943] 1957, p. 88-89).

É a irreverência verde-amarela que acompanha cada brasileiro por toda a sua vida, fazendo-o o mais alegre e despreocupado povo do mundo. [...] 0 brasileiro aprendeu até a rir da própria miséria. Um amigo meu ficou seis meses desempregado e, em lugar do desespero - pois tinha mulher e duas filhas para sustentar - comentava sua falta de trabalho dizendo sempre: "Estou de gerente naquela firma Dias \& Dias Parado." Um povo que leva na galhofa seu próprio drama é um povo que desligou o botão do sofrimento e ligou todas as tomadas da - com o perdão da palavra - avacalhação. Bronca de brasileiro é piada. Sua raiva termina logo numa sátira àquele que o provocou. Quando vemos um brasileiro que não age dentro deste esquema da "avacalhação total", estamos vendo uma coisa falsa. Brasileiro sem este espírito é um homem deslocado. Parece Marya, escrito assim, com "y". (ANYSIO, 1968, p. 62).

Outros observadores realçaram o caráter resistente ou trágico da alegria brasileira:

A consciência popular brasileira se faz inviolável, insubornável, não deixando invadir e dominar, é graças a este escudo brincalhão do riso e da malícia. [...] Não seria esta alegria - além da mestiçagem alvoroçada, da espantosa uniformidade cultural e do brutal desgarramento classista uma das características distintivas dos brasileiros? [...] De onde nos vem esta alegria pagã que não vi em tantos povos exitosos e bem nutridos, pelo mundo afora? [...] Seria ela a compensação dialética que o povo se dá da vida azarosa, famélica e triste que lhe impõem? A vingança do sofredor que, em dias excepcionais, rindo, pilheriando, renega a fome, a dor e o medo do seu cotidiano? (RIBEIRO, 1997, p. xviii-xix).

Aqueles de meus amigos que tiveram a ocasião de visitar o Brasil retornaram todos com o mesmo sentimento dominante: de uma excepcional animação e alegria de viver, junto a um sentido agudo do desastre e da catástrofe iminente. [...] Toda a alegria que pretendesse desconsiderar o trágico, ou ignorá-lo graças à aparente e passageira plenitude de sua felicidade, é necessariamente uma alegria falsificada [...] [0] sentimento da festa e da vida que prevalece no Brasil constitui em contrapartia uma alegria verdadeira, porque constantemente impregnada do sentimento de tragédia. De sorte que a divisa da sabedoria brasileira me parece residir, não nas palavras de Auguste Comte que ornam a bandeira, 
"Ordem e Progresso", mas antes numa fórmula do gênero: "Sejamos felizes, tudo vai mal." (ROSSET, 1989, p. 7-8).

Intérpretes do Brasil de diferentes estirpes tendem a concordar, no entanto, em pelo menos um ponto: nossa peculiar alegria - "sem causa" e "sem dia seguinte", como definira Nabuco ([1900] 1949, p. 153) — é um legado dos negros africanos, trazidos pelos colonizadores para trabalhar de sol a sol em engenhos e minas de ouro:

Foi ainda o negro quem animou a vida doméstica do brasileiro de sua maior alegria. [...] A risada do negro é que quebrou toda essa "apagada e vil tristeza" em que foi abafando a vida nas casas-grandes. Ele que deu alegria aos são-joões de engenho; que animou os bumbas-meu-boi, os cavalosmarinhos, os carnavais, as festas de Reis. Que à sombra da Igreja inundou das reminiscências alegres de seus cultos totêmicos e fálicos as festas populares do Brasil. [...] Nos engenhos, tanto das plantações como dentro de casa, nos tanques de bater de roupa, nas cozinhas, lavando roupa, enxugando prato, fazendo doce, pilando café; nas cidades, carregando sacos de açúcar, pianos, sofás de jacarandá de ioiôs brancos — os negros trabalharam sempre cantando [...] encheram de alegria africana a vida brasileira. Às vezes um pouco de banzo: mas principalmente de alegria. (FREYRE, [1933] 1987, p. 462-63).

Gilberto Freyre faz alusão às consequências funestas do banzo ("a saudade da África"), logo em seguida, nas últimas páginas de Casa grande \& senzala ${ }^{1}$. Com o tempo, tornaram-se incomuns ou nulas as referências àquele espectro sombrio que pairava sobre a labuta cantadeira e a índole festiva dos escravos - o banzo, "moléstia crônica"; "ressentimento entranhado por qualquer princípio", como a nostalgia da pátria ou o "rigor com que os tratavam os seus senhores"; "gravíssima enfermidade", "justa paixão" que "consumia" os "Pretos Africanos" (MENDES, 1812, p. 36-38 e 60-61). Prevaleceu, com folga, a visão harmônica e colorida da presença do negro na cultura brasileira:

No Largo, dançam ranchos e cordões animados por pequenas orquestras, dançam foliões, zé-pereiras, zabumbas. É uma festa extremamente alegre, como, aliás, todas as festas do ritual afro-baiano nas quais os deuses vêm confraternizar com os homens, vêm dançar e cantar com os seus filhos. Não há tristeza na religião dos baianos, tristeza é coisa de branco: quanto a nós, povo mestiço, herdamos a alegria do negro. (AMADO, [1944] 2012, p. 85).

\footnotetext{
1 "Mas não foi toda de alegria a vida dos negros, escravos dos ioiôs e das iaiás brancas. Houve os que se suicidaram comendo terra, enforcando-se, envenenando-se com ervas e potagens dos mandingueiros. O banzo deu cabo de muitos. $\mathrm{O}$ banzo - a saudade da África. Houve os que de tão banzeiros ficaram lesos, idiotas. Não morreram: mas ficaram penando. E sem achar gosto na vida normal - entregando-se a excessos, abusando da aguardente, da maconha, masturbando-se." (FREYRE, [1933] 1987, p. 464). O gesto fatal de comer terra é mencionado pelo poeta Paulo Leminski, em um de seus ensaios sobre a tristeza e o spleen na obra de Cruz e Souza: "Quando um negro 'banzava', ele parava de trabalhar, nenhuma tortura, chicote, ferro em brasa o fazia se mover. Ele ficava ali, sentado, 'banzando', 'banzando'. Vinha o desejo de comer terra. E, comendo terra, voltar para a África através da morte." (LEMINKSI, 2013, p. 25).
} 
Quando visitei Cabo Verde, em companhia de Jorge Amado, vi na ilha de São Vicente uma multidão cantando e dançando, ritmos vivos, cores alegres, gingados corporais e sensuais, explorando a liberdade do corpo. Ao ver essa demonstração popular, falei: "Jorge, olha de onde veio a alegria do povo brasileiro: da África”. 0 forte sangue negro mesclou-se ao do índio e ao do branco, mas dominou a todos. Criou, na mestiçagem, não uma nova raça, mas um povo com essa identidade. A força da alegria invadiu e converteu os mais sombrios e tristes europeus que aqui se misturaram. (SARNEY, 2001).

A luminosa influência africana não teria incidido apenas sobre costumes e festejos pátrios - conformara, também, a exuberância e o molejo dos corpos que exalam e inspiram alegria:

A palavra bunda, por exemplo, com a qual línguas bantas enriqueceram o português do Brasil. [...] Difícil pensar a alegria brasileira sem recorrer à palavra e mentalizar seu objeto. [...] A bunda brasileira, formada graças à herança genética - designada graças à herança linguística - dos africanos, é massa carnal rebolante. [...] É curva e plenitude. A nossa alegria mestiça, em algumas de suas manifestações mais originais, é de base negroafricana. E nasce de um corpo preciso. [...] Mas, além do corpo, existe a visão desse mesmo corpo. 0 nosso modo de lidar com ele. Daí que nossa alegria, manifestando-se em nosso corpo e em sua bunda, seja inseparável da informalidade e do gregarismo brasileiros. (RISÉRIO, 2007, p. 253).

Esse patrimônio cultural, religioso e genético teria sido incorporado pela cultura popular brasileira ou mesmo se introjetado no caráter nacional, sem restrição de raça e de classe, desatrelando-se de crenças religiosas ou de experiências e circunstâncias de vida específicas. Tornou-se, segundo consta, um bem ou uma aptidão distribuído de modo ecumênico: "Duvida? Venha nadar na praia de Ipanema onde a gurizada bem nutrida se doura ao sol o ano inteiro. Depois, espiche um pouco para ver meu povão dançando o Carnaval no Sambódromo." (RIBEIRO, [1987] 2008, p. 21). É um contentar-se com o corpo, um satisfazer-se com pouco, característico dos remediados; é um tranquilo desfrutar dos prazeres da vida, apanágio dos abonados.

Joie de vivre não se afirmaria, por aqui, como um ideal contestatório, uma postura crítica dos excessos civilizatórios, um repúdio intelectual do intelectualismo, como teria ocorrido na França (HARROW; UNWIN, 2009; ROLDAN, 2012) - consistiria em uma arte espontânea, um modo natural de conduzir a vida, em que a existência flui desafogada, sem as agonias metafísicas ou as obsessões materiais que atormentam europeus e norte-americanos.

Não se pode subestimar a persistência dessas representações convencionais: o site da revista Le nouvel observateur anunciou, em dezembro de 2014, a lista dos escritores convidados para representar o Brasil no Salão do Livro de Paris, no ano seguinte. Para ilustrar a 
matéria sobre o evento que pretendia "refletir a riqueza da produção intelectual" do país homenageado, Le nouvel observateur selecionou personagens com perfil nada erudito: trajando biquínis e shorts verde-amarelos, três mulheres empunhavam a bandeira nacional, em uma praia ensolarada. A legenda anunciava: "torcedoras brasileiras na última Copa do Mundo" (na realidade, as moças eram dançarinas inglesas). Em entrevista ao jornal $O$ Globo, o responsável pela sessão de literatura do semanário francês tentou justificar a foto controversa:

Em vez de destacar apenas um dos 48 autores da lista, tivemos a ideia de mostrar uma bandeira do Brasil. Como aquela foto estava no banco de imagens, nossa intenção foi dar um zoom na bandeira, sem que aparecessem as modelos. 0 zoom não funcionou e só percebemos algumas horas mais tarde. São coisas que acontecem. (TORRES, 2014).

Furtivo e resistente, o enquadramento estereotipado não é reproduzido apenas pelo olhar estrangeiro. Em 1994, o Brasil foi escolhido como "país tema" da Feira de Livros de Frankfurt, ficando responsável pela montagem dos estandes de exibição de nossos expoentes, predicados e triunfos culturais. Conforme observou a historiadora Lilia Moritz Schwarcz, os organizadores se mantiveram impecavelmente fiéis ao lugar-comum:

0 retrato era de um Brasil sem brilhos ou destaques individuais, marcado pelo coletivo e por uma sociedade alegre, despreocupada, subjetiva e, portanto, singular. Triste país sem intelectuais ou pensadores a serem reconhecidos. (SCHWARCZ, 1994, p. 2).

A nação homenageada oferecia aos visitantes "[...] uma imagem ainda mais caricata do que aquela que nos é normalmente atribuída [...]". Os clichês se alastravam por todos os espaços da exposição. Na seção "cotidiano" figuravam autodefinições corriqueiras: “0 futebol é a religião local.”; “No dia-a-dia só se fala de política, mulher e futebol.”; "A alegria da vida é o grande trunfo de nossa identidade.". Para simplificar a compreensão dos textos elementares, uma tela de TV alinhava "[...] cenas de futebol, carnaval, indígenas na mata e muitas mulheres de biquíni; exatamente como o diabo gosta [...]”. O espaço dedicado ao êxito de nossa mistura racial tampouco fugia do previsível:

Fotos e mais fotos (que mais se pareciam com um anúncio da Benetton) mostravam indivíduos sorridentes das mais diferentes origens e condições. Brancos, morenos, loiros, ruivos, vermelhos e amarelos; um verdadeiro "Carrefour" de cores representava a nossa falta de padrão racial. (SCHWARCZ, 1994, p. 2).

A alegria se consolidou, em síntese, como um componente marcante e tenaz da brasilidade, ingrediente decantado em verso e prosa, enaltecido em relatos de viajantes saudosos 
e ressaltado em discursos políticos e publicitários. Trata-se de um elemento constitutivo da identidade, da imagem e da reputação do país - ou seja, da percepção que temos acerca das qualidades distintivas fundamentais do nosso povo, no que concerne a valores, aspirações, paixões dominantes, disposição psicológica e moral; das impressões que somos encorajados a transmitir socialmente; das imagens e das narrativas que projetamos no exterior; do conceito que usufruímos mundo afora, o nosso tão comentado encanto turístico ou utópico.

A alegria brasileira exaltada por acadêmicos, literatos e propagandistas de toda espécie não se adéqua bem aos parâmetros do conceito científico de emoção - categoria psicológica secular que, a partir do século XIX, passou a abranger e redefinir uma constelação de fenômenos da vida afetiva que filósofos clássicos e antigos escritores cristãos (como Santo Agostinho e São Tomás de Aquino) qualificavam de apetites, afetos, paixões ou sentimentos (DIXON, 2003). Os retratos corriqueiros do Brasil raramente privilegiam o enfoque de uma alegria privada, episódica, de curta duração, estimulada por objeto ou evento bem definido. Em vez de uma condição emocional transitória e direcionada, os observadores detectam um temperamento habitualmente bem-humorado - um estado de ânimo duradouro, uma leveza de espírito constante, uma disposição favorável para enxergar o mundo, em geral, através de "lentes afetivas positivas", tomando de empréstimo a expressão usada por Sarah Ahmed, em seu instigante ensaio de fenomenologia política (AHMED, 2014, p. 14). Não raro, jornalistas e escritores abordam a alegria como a tonalidade afetiva predominante nos espaços públicos - uma alegria insuflada pelo clima tropical, alentada pela beleza paisagística, irradiada pelo sol e pela brisa do mar. Como uma corrente afetiva sinuosa, essa alegria atmosférica impregnaria os ambientes, circularia entre os corpos, contagiando-os de jovialidade, boa vontade, espírito de camaradagem e de festa.

Difusa e penetrante, a excepcional alegria brasileira encontraria sua mais notória vitrine no Rio de Janeiro, capital do carnaval, folia que enseja e encena fantasias e esperanças coletivas profundas de união sensual e de congraçamento social. Para muitos admiradores, trata-se de uma manifestação paroxística das "vibrações" e das "forças" que, usualmente, reverberam como ondas sonoras pela cidade, em ritmo acelerado ou mais cadenciado, atravessando, energizando e movimentando corpos, dinamizando interações e encontros.

As caracerísticas do carioca ressaltam, ao mesmo tempo, como resultantes e condicionadoras nas grandes festas com que ele enche o ano e que ficam vivendo na sua alma até a sua substituição pela subsequente. 0 carnaval, que é a primeira e a mais importante de todas, é um delíro de alegria, confraternização, musicalidade, harmonia, dança, ritmo, de interrelacionamento de todas as nossas raças e a prova de que no Rio de 
Janeiro não há nenhum preconceito erótico. [...] Alegria da carna que vale - carnaval. (NAVA, [1983] 2004, p. 206).

Ora, quem não mora no Rio deve aprender o seguinte: o Rio é praticamente o mês de fevereiro; quem vive aqui os dias quentes de fevereiro viveu tudo (ou quase tudo) da graça, da euforia, carioca. É desamarrar a gravata, meter o calção e sair por aí; tudo acontece. É embeber-se de fevereiro, pois o mês vai terminar de repente, como o chão que falta, e é preciso viver intensamente quando nos sentimos emaranhados na armadilha do efêmero. [...] Fevereiro é um resumo da existência carioca: curto, agitado, sensual, encalorado, colorido, dourado, irreal, fevereiro tem todos os adjetivos da fantasia. (CAMPOS, [1989] 2005, p. 91-93).

A alegria é a melhor coisa que existe e no Rio de Janeiro já é parte da paisagem. Lugar que inventou a Bossa Nova, revelou o samba e globalizou o carnaval. Nenhum outro estado foi tão cantado, fotografado, ou mesmo abençoado com um povo tão amável e disposto a sorrir. O Rio de Janeiro é, na verdade, um estado de espírito. E começa uma nova década querendo ser mais feliz do que nunca. (RIO DE JANEIRO, 2011, doc. não paginado).

Na Cidade Maravilhosa, a vida seria como um pêndulo que oscila entre o êxtase festivo e o relaxamento prazeroso:

Apesar da desigualdade e de sua frenética e multifacetada realidade nas ruas, o Rio consegue manter, ao mesmo tempo, uma atmosfera agradável e descontraída. 0 Carnaval é a sua expressão externa mais dinâmica, no qual pessoas pobres, mascaradas alegremente como reis e rainhas, são acompanhadas, nos movimentos implausivelmente rápidos do samba, por pessoas ricas vestidas com fantásticos trajes brilhantes. Não importa quão grandiosa ela se torne, a festa do Carnaval significará sempre infinitamente mais para os cariocas do que para os milhares de empolgados visitantes que engrossam as suas fileiras a cada ano. Diariamente, também, moradores do Rio se reúnem para praticar esporte e relaxar em suas praias, com as grandes dimensões de Copacabana e de Ipanema sendo, provavelmente, as mais famosas extensões de areia do planeta. (COATES; MARSHALL, 2009, p. 5-6).

Em março de 2013, o jornal O Globo divulgou os resultados de uma exclusiva pesquisa de opinião destinada, somente, a proclamar o óbvio: a felicidade reside na Cidade Maravilhosa ("cidade dos encontros descontraídos e dos discursos descomprometidos"); o carioca se considera mais alegre do que os habitantes de outros estados do país; “[...] no Rio, as pessoas são felizes por causa da praia, da paisagem [...]"... 0 alto astral dos moradores, a malandragem ("leia-se jogo de cintura"), a beleza natural, a sensualidade e a camaradagem foram apontados (em ordem descrente de importância) como os fatores responsáveis pela primazia nacional no quesito contentamento (DALE, 2013).

A enquete deu origem a uma reportagem de capa do suplemento dominical Revista $O$ Globo, sucedida por mais três matérias veiculadas na editoria Rio (ALVES, 2013; MEROLA, 
2013; LIMA, 2013). Entre outras revelações, a pesquisa identificou "[...]os melhores representantes da alegria de viver carioca [...]". A lista dos nomes mais citados pelos 450 participantes da pesquisa (com idade entre 18 e 60 anos, residentes na Zona Sul, na Barra, no subúrbio e em comunidades pacificadas) é bastante eclética: além do campeão Zeca Pagodinho ("que ensinou a importância de deixar a vida nos levar"), figuram Regina Casé ("que conhece a periferia como a palma da mão e adora fazer compras na Saara"), Xuxa ("pioneira em driblar a cidade partida. Cansou de levar grupo de funk para o seu programa, quando o gênero sequer engatinhava rumo à Zona Sul") e o "superpaulistano" Luciano Huck ("que diz que o Rio o ajudou a ser uma pessoa mais aberta, mais democrática e, consequentemente, mais feliz").

Os depoimentos dos ícones do neopopulismo televisivo desmentiam a existência de uma "cidade partida" (rótulo popularizado, em meados dos anos 1990, pelo livro homônimo do jornalista Zuenir Ventura). Todos se gabavam de transitar por diversas regiões da cidade, usufruindo da geografia generosa, da mistura social sem preconceitos e do clima de efervescência cultural. A repórter que assina a matéria de $O$ Globo reforçou as declarações das celebridades: "No Rio de agora, ensolarado como sempre, sem áreas de exclusão e cada vez mais democrático, cabem como legítimos exemplos da alegria local famosos que sempre apostaram além da orla da Zona Sul." (LIMA, 2013).

Um dos tópicos da série "Eu sorrio, Eu sou Rio" foi o impacto do anuncio da realização na cidade de eventos como a Copa do Mundo e as Olimpíadas. De acordo com a pesquisa encomendada pelo Globo, 68\% dos cariocas acreditavam que os jogos tornariam o Rio mais feliz. A publicitária responsável pela sondagem afirmou que "O momento mais do que especial" que a cidade experimentava tinha elevado ainda mais a autoestima dos moradores: "0 mundo está apaixonado pelo Rio. E o carioca está se achando...”. (DALE, 2013, p. 36).

Para explicar a influência dos jogos "à luz da ciência", o jornal entrevistou João Ascenso, "psicólogo social e aluno de neurociências no Instituto D’Or/UFRJ" e "diretor de uma empresa que ajuda pessoas a desenvolver, de forma consciente, a felicidade". 0 especialista citou "pelo menos seis teorias estudadas em vários países". Duas delas, que tratavam da esperança e da autoeficácia, se encaixariam perfeitamente no momento vivido pelos moradores do Rio:

A primeira, da esperança, aborda como a possibilidade de um futuro melhor faz as pessoas se sentirem mais felizes. A segunda, de acordo com a teoria do psicólogo canadense Albert Bandura, fala de autoeficácia, do sentimento de que se é capaz de realizar coisas: se o Rio pode fazer 
grandes eventos, o cidadão comum também pode se apropriar dessas realizações, o que faz com que se sinta mais feliz. (MEROLA, 2013).

Em que pese o seu notável apreço pelo lugar-comum, a sequência de matérias de $O$ Globo não chegou a afirmar que tudo são flores na vida dos cariocas. 0 jornal revelou, por exemplo, que "a deficiência no sistema de saúde" tirava o sorriso do rosto do barraqueiro Ronaldo Correia, "o Panela", de 46 anos, pai de três filhos - "Meu coração fica mortificado quando fico sabendo que uma criança morreu no Hospital Salgado Filho, no Méier onde nasci, por falta de neurocirurgião." (DALE, 2013, p. 36). Uma ressalva da repórter interrompe, abruptamente, a lamentação: "Ele próprio tem saúde de sobra para trabalhar, sol a sol, na barraca demarcada por uma bandeira da Mangueira, no Leblon, alugando banheiras de plástico e vendendo cerveja [...]". Logo em seguida, Panela ratifica a predisposição para o bom humor: "Posso estar revoltado, mas quando vejo, da minha laje, o sol nascendo atrás das Ilhas Cagarras, todos os problemas desaparecem." (DALE, 2013, p. 36).

Simples assim.

Decorrido pouco mais de um ano, o jornal corrigiu suas previsões sobre a ascensão do já elevadíssimo bom humor dos cariocas: "Rio bipolar. Protestos, obras, trânsito, preços altos, serviços ruins: bem-humorado por natureza, o carioca vive tempos de 'inferno astral'", diagnosticou a matéria de capa da Revista $O$ Globo, ilustrada por duas fotos do ator Leandro Hassum, dispostas lado a lado, uma com a cara emburrada, outra com a expressão eufórica, pretensa tradução visual da alternância de estados depressivos e maníacos. A abertura da reportagem hesita entre a preservação do dileto perfil emocional do carioca (legitimado pelo chavão "todo clichê tem um fundo de verdade") e o reconhecimento de uma substancial mudança de estado de ânimo:

\begin{abstract}
Alguma coisa está fora da nova ordem carioca. Os adjetivos habitualmente usados para classificar o típico morador da cidade - que, como todo clichê, têm sua verdade - estão ofuscados por outros que não costumavam passear pelo vocabulário habitual do Rio. Hospitaleiro, bemhumorado, solar, alto-astral, relaxado, extrovertido - o carioca é tudo isso, mas também anda irritado, melancólico, impaciente, de má vontade até para decorar as ruas para a Copa. Mal-humorado com o trânsito caótico, as obras e manifestações que deixam os engarrafamentos ainda maiores, os preços altos para serviços ruins. É como se o Rio estivesse bipolar. (VELASCO, 2014, p. 22).
\end{abstract}

Pacientes são diagnosticados como portadores de transtorno bipolar quando apresentam, no entendimento dos psiquiatras, graves e incapacitantes flutuações de humor, marcadas por períodos duradouros de sentimentos de tristeza, desesperança e isolamento e por 
fases de atividade frenética e de euforia ou irritação desmedida. Na linguagem figurada de $O$ Globo, a categoria nosológica não é usada para assinalar depressões e exaltações anormais de humor - indica, antes, uma oscilação entre um quadro atípico de mau humor (ainda que associado a fatores bastante concretos) e o usual bom humor carioca (presumidamente inabalável). Delineia-se, assim, um self normativo, cujo modelo superior de humor funciona, tradicionalmente, como parâmetro para avaliar padrões de condutas e atitudes, para identificar os ranzinzas, os desmancha-prazeres, os enfermos e os maus sujeitos (como discrimina o famoso Samba da minha terra, de Dorival Caymmi: "Quem não gosta de samba/ bom sujeito não é/É ruim da cabeça/ou doente do pé”).

A exibição graciosa de um mapa astral do Rio de Janeiro e a característica leveza do texto da Revista $O$ Globo não conseguem desanuviar, inteiramente, a atmosfera algo sombria da matéria, gerada pelo tom aborrecido de alguns depoimentos. Artistas e cientistas sociais reclamaram de obras inconclusas, da violência urbana, da carestia, dos engarrafamentos habituais, da crescente "falta de compostura" dos motoristas, do "desconforto" com greves e protestos que pioravam o trânsito, das "reações exacerbadas nas redes sociais" (convertidas em um "sistema de fiscalização da vida do outro", patrulhamento que recriminava, por exemplo, aqueles que pretendiam torcer pelo Brasil na Copa do Mundo).

A matéria "De mal com o bom humor" foi veiculada exatamente um ano depois das "Jornadas de Junho" - manifestações que eclodiram em todo o país, reivindicando serviços públicos de qualidade e o combate efetivo à corrupção, entre outras demandas difusas. Manchetes da imprensa estrangeira destacaram "la colère populaire" ou "la rabia social" que se espraiava pelo Brasil. "Onde estava escondida essa raiva coletiva?", indagou-se, por aqui, a jornalista de economia Thais Herédia, "perplexa" com a falta de liderança e a escalada de violência dos protestos (HERÉDIA, 2013). A irritação das massas contrariava não só o clima de festa previsto para a chegada de grandes eventos esportivos, como também as pesquisas que apontavam o crescimento dos índices de otimismo e de felicidade da população, graças a recentes conquistas econômicas.

Na visão do historiador José Murilo de Carvalho, os protestos constituíram uma "expressão positiva de insatisfações com mazelas reais do país", sinalizando o "fim do reinado do bom humor", inclusive no simbólico território carioca.

No Rio chama mais a atenção por ser a cidade exaltada como ícone do bom humor. [...] Os brasileiros parecem estar dizendo que não aceitam mais o futebol como circo que os distraia dos problemas do cotidiano, que ganhar a Copa de futebol é bom, mas que é mais importante ganhar outras Copas, 
a da educação, da saúde, da mobilidade urbana, da segurança individual. É um progresso democrático. (VELASCO, 2014, p. 24).

Em um artigo publicado em 1998, José Murilo de Carvalho esmiuçou os dados de duas pesquisas - uma de âmbito nacional, feita pela Vox Populi, a pedido da revista Veja; outra restrita à Região Metropolitana do Rio de Janeiro, realizada em parceria pelo Centro de Pesquisa e Documentação de História Contemporânea do Brasil (CPDOC) da Fundação Getulio Vargas e pelo Instituto de Estudos da Religião (Iser) — que permitiam avaliar a autoimagem do brasileiro naquele momento. Na pesquisa CPDOC-FGV/Iser, solicitou-se aos entrevistados que selecionassem, de uma lista de adjetivos, aqueles que definiam melhor os brasileiros e os cariocas. O brasileiro foi classificado como "sofredor", "trabalhador", "alegre", "conformado", em ordem decrescente de escolha ${ }^{2}$. Os mesmos atributos definiriam o carioca, mas em outra ordem: "alegre", "sofredor", "conformado", "trabalhador". Os resultados da pesquisa VP/Veja eram similares: as quatro características dos brasileiros mais mencionadas foram, em ordem decrescente: "trabalhador/lutador", "divertido", "acomodado", "solidário" e "sofredor".

A autoimagem do brasileiro, configurada a partir da análise das duas enquetes, comportava um aspecto intrigante, como destacou Carvalho:

O que, porém, chama a atenção no conjunto das características mais votadas é a ideia de passividade: trabalho, sofrimento, conformismo. Pior ainda, tudo isto é temperado pela alegria. Pode-se perguntar se não há contradição das pessoas que anotaram ao mesmo tempo sofrimento e alegria. Parece-me que não. Sofredor pode indicar a ideia de vítima do governo, das circunstâncias, do destino. A alegria seria a maneira de enfrentar a desgraça. $O$ brasileiro seria um sofredor conformado e alegre. Descrição perfeita desta autopercepção é o nome de um bloco carnavalesco do Recife: "Nóis sofre mas nóis goza". (CARVALHO, 1998, p. 36).

A referida passividade - possivelmente inócua, do ponto de vista moral e psicológico - se constituía em um elemento preocupante, quando examinada sob a ótica política.

[D]o ponto de vista político e cívico, é a própria definição do não-cidadão, do súdito que sofre, conformado e alegre, as decisões do soberano. 0 povo se vê como vítima, como paciente e não como agente da história. 0 povo não se vê como responsável pelo que acontece no país, não apenas porque não participa, mas também por não se considerar cúmplice da ação de seus representantes, mesmo quando os elege. Não se vê como agente direto nem indireto da política. Não se enquadra na democracia antiga nem na moderna. Desse modo, só lhe restam as belezas naturais, cada vez mais destruídas por ele próprio. No dia em que lhe faltarem as belezas, o último

\footnotetext{
${ }^{2}$ Aquelas foram as características que obtiveram a indicação de $50 \%$ ou mais dos entrevistados; os outros qualificativos disponíveis eram: "revoltado"; "pacífico"; “honesto"; "malandro"; "violento"; "preguiçoso"; “egoísta”; “desonesto".
} 
refúgio de orgulho talvez seja o samba e o futebol. "Nóis" sofre na política mas "nóis" goza no carnaval e no tetra, quem sabe no penta. (CARVALHO, 1998, p. 36).

As Jornadas de Junho representaram, na opinião de muitos analistas de primeira hora, um enérgico despertar de paixões e emoções imprescindíveis para o engajamento e a atividade política, como a indignação e a ira cívica. Os desdobramentos das manifestações populares não foram, todavia, exatamente os previstos ou desejados pelos setores mais progressistas da nossa vida pública. As indignações logo se revelaram, em muitos casos, demasiadamente parciais, seletivas, interesseiras ou retrógradas. 0 lugar de "vítima" continuou convidativo, só que agora tende a ser ocupado com ostensiva amargura ou ódio ruidoso. "Cidadãos de bem" deploram, enojados, os erros e a imoralidade dos governantes, confabulando vinganças. Reverberam, por toda parte, ondas contínuas de ressentimentos, agitadas pelo descumprimento de promessas políticas de igualdade e pela frustração de sonhos consumistas de felicidade ou, ao contrário, provocadas pela ampliação, supostamente imerecida, das possibilidades de acesso de novos segmentos sociais a estas mesmas benesses, promessas e direitos.

Filósofos, cientistas sociais e historiadores costumam conceituar o ressentimento como uma "paixão social" ou um "sentimento moral" associado tanto ao sofrimento de uma ofensa ou de uma punição considerada imerecida quanto à observação do sucesso e do status superior alcançados por outrem, sem o devido mérito. Nesse sentido, a experiência do ressentimento, vinculada à percepção dolorosa de uma falta de merecimento, constitui a antítese da experiência da alegria, que pressupõe ou admite a gratuidade das gratificações. De acordo com Potkay (2007), a alegria está associada, habitualmente, à experiência de um desejo realizado sem a interferência direta do nosso esforço, como um sucesso imprevisto ou o encontro do ser amado - acontecimentos e pessoas que surgem, mais ou menos de surpresa, em nossas vidas, como fruto da sorte, resultado da ajuda alheia ou obra da graça divina. A alegria, em tese, não nos custa nada, tende a ser gratuita, conforme sugere a raiz etimológica do vocábulo: "Em grego, a alegria (chara) está etimologicamente relacionada à 'graça' (charis), o dom concedido sem contrapartida, e às vezes não se distingue claramente dela.".

Atualmente, os brasileiros se mostram constantemente incomodados com as alegrias injustificadas usufruídas por outros indivíduos ou grupos sociais. Representantes da classe média manifestam a ansiedade da proximidade (simbólica, imaginária ou efetiva) dos emergentes, um ressentimento do favorecimento, expresso, em regra, na linguagem convencional 
do asco. Anônimos de todas as classes manifestam contentamento com os tombos literais ou os rebaixamentos simbólicos das celebridades, detentoras da fama desprovida de mérito. Os alemães chamam de Schadenfreude esse júbilo que sentimos, ocasionalmente, pela desgraça alheia; o deleite com o fiasco e as desventuras de terceiros (Schaden significa dano, infortúnio; freude, alegria, satisfação). A palavra não foi incorporada ao nosso idioma, mas sabemos bem do que se trata: de dedo em riste, um indivíduo chama a atenção para a queda de outrem, ocorrência que lhe causa regozijo, em vez de compaixão ou de piedade. Os deslizes e as derrapadas dos famosos promoveriam, pelo menos no plano imaginário, um reequilíbrio na balança de status, poder, estima, entre outros fatores comparativos individuais ou intergrupais.

Recanto de anônimos ressentidos, a Internet parece ter escancarado aversões latentes e "sentimentos feios" (NGAI, 2005) encobertos, costumeiramente, pelas máscaras sociais da alegria brasileira. Redes sociais virtuais - concebidas para o compartilhamento de memórias aprazíveis, instantes festivos, mensagens e produtos "inspiradores" - acabam servindo, também, para dar vazão a um volume notável de comentários e testemunhos raivosos que escapam, inteiramente, da proposta de contágio emocional positivo. Facebook, Youtube e outras plataformas da felicidade on-line se convertem, amiúde, em caixas de ressonância da fúria de legiões de consumidores e cidadãos revoltados.

A desinibida virulência das interações virtuais contribui para estremecer os alicerces da "imagem mítica do brasileiro simpático", conforme salientou Manuel Castells, em entrevista de grande repercussão:

\begin{abstract}
A imagem mítica do brasileiro simpático existe só no samba. Na relação entre as pessoas, sempre foi violento. A sociedade brasileira não é simpática, é uma sociedade que se mata. Esse é o Brasil que vemos hoje na internet. Essa agressividade sempre existiu.

A única coisa que a internet faz é expressar abertamente o que é a sociedade em sua diversidade. Trata-se de um espelho. Como hoje não precisam passar pelos meios tradicionais de comunicação, as pessoas aparecem como realmente são.

[...] Na internet, um racista ou um sexista pode facilmente encontrar outros racistas e sexistas que, em seu entorno social, não podem se declarar abertamente assim. Na rede, não há constrangimento e se abre a possibilidade de expressão espontânea da sociedade. E o que ocorre? Nos damos conta de que a sociedade não é tão boa e angelical como gostaríamos que fosse.

Vemos que, na verdade, a sociedade é bastante má. No Brasil e em todos os outros países. (COLOMBO, 2015, doc. eletrônico).
\end{abstract}

Para reconhecer o papel da Internet na desconstrução da imagem edulcorada da índole do nosso povo, não é preciso concordar com a tese algo simplista de que o ambiente vir- 
tual funcionaria, puramente, como um espelho, sem distorções, da alma brasileira ou como uma janela que permite contemplar, diretamente, nossas emoções mais autênticas. Não se podem menosprezar as especificidades dos processos comunicacionais nas plataformas interativas, cuja própria estrutura ajuda, muitas vezes, a acirrar os ânimos e a incrementar controvérsias e conflitos (FORTUNATI, 2012), nem tampouco ignorar as intervenções estratégicas daqueles que ambicionam capitalizar em cima do apelo da retórica e da performance do ódio. As redes sociais se configuram, de fato, como uma estrutura tanto de mediação quanto de geração de ressentimentos que se alastram por toda a sociedade.

Conforme exemplifiquei nos primeiros parágrafos deste artigo, escritores e jornalistas atuaram, de maneira decisiva, para notabilizar o Brasil como o "país da alegria". Agora, sob o impacto de recentes transformações sociais e acontecimentos políticos, são eles também que ajudam a promover, sistematicamente, uma reconsideração da nossa autoimagem. As citações que reproduzo a seguir, pinçadas entre outras tantas possíveis, evidenciam a presença de elementos comuns na construção de novas narrativas sobre a cultura nacional e o caráter brasileiro. Demonstram, por exemplo, a relevância da insatisfação, da intolerância, da agressividade, do machismo e do preconceito nos discursos e nas representações mais recentes que a nossa sociedade vem produzindo a respeito de si mesma.

Um dos estereótipos mais arraigados em relação à cultura brasileira é a de que somos um povo alegre, hospitaleiro e festeiro. Ora, de cada 100 assassinatos ocorridos no mundo, 13 verificam-se no Brasil. 0 pensamento machista domina a sociedade de alto a baixo - uma em cada três pessoas (homens e mulheres) acredita que o estupro ocorre por causa do comportamento feminino. A violência no trânsito é responsável pela terceira maior causa de óbitos no Brasil, logo após as doenças cardíacas e o câncer.

[...] Talvez tenhamos que repensar o caráter do brasileiro. Afirmar que os brasileiros somos naturalmente alegres é desconhecer a insatisfação latente que vigora nos trens, ônibus e vagões de metrô lotados. Falar que os brasileiros somos tolerantes é desconhecer nosso machismo, nossa homofobia, nosso racismo. Dizer que os brasileiros somos solidários é desconhecer nossa imensa covardia para assumir causas coletivas. (RUFFATO, 2015, doc. eletrônico).

A ideia do brasileiro como um povo cordial nunca resistiu à realidade histórica de uma nação fundada na eliminação do outro, os indígenas e depois os negros, lógica que persiste até hoje. Me refiro não ao "homem cordial", no sentido dado pelo historiador Sérgio Buarque de Holanda (1902-1982) em seu seminal Raízes do Brasil, mas no sentido que adquiriu no senso comum, o do povo afetuoso, informal e hospitaleiro que encantava os visitantes estrangeiros que por aqui aportavam. 0 Brasil que, diante da desigualdade brutal, supostamente respondia com uma alegria irredutível, ainda que bastasse prestar atenção na letra dos sambas para 
perceber que a nossa era uma alegria triste. Ou uma tristeza que ria de si mesma.

[...] Os linchamentos dos corpos nas ruas do país e o strip-tease das almas nas redes sociais desmancharam a derradeira ilusão da imagem que importávamos para nosso espelho. Quando tudo o mais faltava, ainda restavam os clichês para grudar em nosso rosto. Acabou. Com tanto silicone nos peitos, nem o país da bunda somos mais. (BRUM, 2015, doc. eletrônico).

Nas primeiras décadas do século $\mathrm{XX}$, eram triviais os diagnósticos da "índole tristonha e apática do nosso povo" (BILAC, [1908] 1996, p. 287). A partir dos anos 1930, reduziram-se, paulatinamente, as alusões ao acabrunhamento roceiro ou ao marasmo citadino que assemelhava o brasileiro a um "cipreste humano, sempre debruçado sobre a cova em que jaz sepultada a sua alegria" (BILAC, 1906, p. 2); a um "sombrio urupê de pau podre a modorrar silencioso no recesso das grotas" (LOBATO, [1918] 1994, p. 177); a um jaburu, ave de "estatura avantajada, pernas grossas, asas fornidas" e que "passa os dias com uma perna cruzada na outra, triste, triste, daquela 'austera e vil tristeza'” (ABREU, [1916] 2012).

Com o apoio de reinterpretações intelectuais e de planejadas ações governamentais, superamos as "ideologias do pessimismo" (LEITE, [1968] 2007) e tornamo-nos o país da alegria. Não se pode assegurar que essa imagem estereotipada, essa representação uniformizadora e essencialista - tão fortemente inscrustrada em nossas práticas e nossas produções culturais - esteja fadada, irremediavelmente, a extinguir-se.

O certo é que testemunhamos um inaudito reconhecimento público da presença do ressentimento em nossa história, nossas relações sociais e nossa vida política. Qual o papel dos diferentes espaços comunicacionais e artefatos midiáticos na promoção das atuais revisões do caráter brasileiro e da constituição da identidade nacional? Buscar respostas para essa interrogação central é, sem dúvida, uma das contribuições mais significativas que o campo da Comunicação pode oferecer para pensar o Brasil contemporâneo. 


\section{Referências}

ABREU, Capistrano de. Carta a João Lúcio de Azevedo [1916]. In: PRADO, Paulo. Retrato do Brasil: ensaio sobre a tristeza brasileira. São Paulo: Companhia das Letras, 2012.

AHMED, Sara. Not in the Mood. New Formations: a journal of culture/theory/politics, London, v. 82, n. 82, p. 13-28, 2014.

ALVES, Maria Elisa. A cara da felicidade muito além da Zona Sul. 0 Globo, Rio de Janeiro, p. 20, 6 mar. 2013.

AMADO, Jorge. Bahia de todos-os-santos: guia de ruas e mistérios de Salvador. São Paulo: Companhia das Letras, 2012 [1944].

ANDRADE, Mário de. 0 turista aprendiz. Rio de Janeiro: Duas Cidades, 1976 [1929].

ANYSIO, Chico. Brasil, o país do amanhã. Realidade, São Paulo, p. 62-64, maio de 1968.

BILAC, Olavo. Exposição nacional. In: DIMAS, Antonio (Org.). Vossa insolência: crônicas, São Paulo: Companhia das Letras, 1996 [1908]. p. 283-288

BILAC, Olavo. A tristeza dos poetas brasileiros. Revista Kosmos, Rio de Janeiro, p. 1, jan. 1906,.

BRUM, Eliane. Por quem rosna o Brasil. El País, Madrid, 3 ago. 2015. Disponível em:

<http://brasil.elpais.com/brasil/2015/07/20/opinion/1437400644_460041.html>. Acesso em: 4 ago. 2015.

CAMPOS, Paulo Mendes. Rio de Janeiro. In: CAMPOS, Paulo Mendes.

Brasil brasileiro: crônicas do país, das cidades e do povo. Rio de Janeiro: Civilização Brasileira, 2005 [1989]. p. 91-94

CARVALHO, José Murilo de. 0 motivo edênico no imaginário social brasileiro. Revista Brasileira de Ciências Sociais, São Paulo, v. 13, n. 38, p. 19-43, 1998.

COATES, Robert; MARSHALL, Oliver. The Rough Guide to Rio de Janeiro. Londres: Rough Guides, 2009.

COLOMBO, Sylvia. Simpatia do brasileiro é um mito, diz sociólogo Manuel Castells. Folha de S. Paulo, São Paulo, 18 mai. 2015. Disponível em:

<http://www1.folha.uol.com.br/poder/2015/05/1630173-internet-so-evidencia-violenciasocial-brasileira-afirma-sociologo-espanhol.shtml>. Acesso em: 20 mai. 2015.

DALE, Joana. Eu sorrio, eu sou Rio. Revista 0 Globo, Rio de Janeiro, p. 34-46, 3 mar. 2013.

DIXON, Thomas M. From passions to emotions: the creation of a secular psychological category. New York: Cambridge University, 2003. 
FORTUNATI, Leopoldina. Il risentimento online. In: DI FRAIA, Guido; RISI, Elisabetta (Orgs.). L'umano risentire: trame e manifestazioni sociali di un sentimento della tarda modernità. Milão: Ledizioni, 2012. p. 77-102

FREYRE, Gilberto. Casa-grande e senzala. Rio de Janeiro: José Olympio, 1987 [1933].

HERÉDIA, Teresa. Onde estava escondida essa raiva coletiva?. G1, Rio de Janeiro, 21 jun. 2013. Disponível em: <http://g1.globo.com/platb/thaisheredia/2013/06/21/onde-estavaescondida-essa-raiva-coletiva/>. Acesso em: 24 jun. 2013.

HARROW, Susan; UNWIN, Timothy (Orgs.). Joie de vivre in French literature and culture: essays in honour of Michael Freeman. Amsterdam: Rodopi, 2009.

LEITE, Dante Moreira. 0 caráter nacional brasileiro: história de uma ideologia. São Paulo: UNESP, 2007 [1968].

LEMINSKI, Paulo. Blues e sousa. In: LEMINSKI, Paulo. Vida: Cruz e Sousa, Bashô, Jesus e Trótski. 4 biografias. São Paulo: Companhia das Letras, 2013. p. 23-27

LIMA, Ludimilla de. 0 "Arpex" é como a luz no coração dos cariocas. 0 Globo, Rio de Janeiro, p. 16, 5 mar. 2013.

LOBATO, Monteiro. Urupês. São Paulo: Brasiliense, 1994 [1918].

MEDEIROS, Maurício de. Psicologia da anedota e do riso. In: FRIEIRO, Eduardo. 0 brasileiro não é triste. Rio de Janeiro: INL, 1957 [1943]. p. 88-89.

MENDES, Luis Antonio de Oliveira. Discurso acadêmico ao programa. In: MENDES, Luis Antonio de Oliveira. Memorias economicas da Academia Real das Sciencias de Lisboa, para o adiantamento da agricultura, das artes, e da industria em Portugal, e suas conquistas. Tomo IV. Lisboa: Tipografia da Academia, 1812, p. 1-64

MEROLA, Ediane. Novos tempos com promessa de felicidade. 0 Globo, Rio de Janeiro, p. 14, 4 mar. 2013.

NABUCO, Joaquim. Minha formação. São Paulo: Instituto Progresso Industrial, 1949.

NAVA, Pedro. 0 círio perfeito. São Paulo: Giordano, 2004 [1983].

NGAI, Sianne. Ugly feelings. Cambridge: Harvard University, 2005.

POTKAY, Adam. The story of joy: from the Bible to late Romanticism. Cambridge: Cambridge University, 2007.

RIBEIRO, Darcy. Brasil-Brasis. In: RIBEIRO, Darcy. Utopia Brasil. São Paulo: Hedra, 2008 [1987].p. 21-36

RIBEIRO, Darcy. Macunaíma. In: ANDRADE, Mário. Macunaíma: o herói sem nenhum caráter. Edição crítica. São Paulo: ALLCA XX, 1997. p. XVII-XXII 
RIBEIRO, João Ubaldo. Viva o povo brasileiro. Rio de Janeiro: Nova Fronteira, 1984.

RIO DE JANEIRO (Estado). Rio de Janeiro. Marca registrada do Brasil. Rio de Janeiro: Governo do Estado do Rio de Janeiro, 2011. Pôster de campanha publicitária.

RISÉRIO, Antonio. Palavras, palavras, palavras. A utopia brasileira e os movimentos negros. São Paulo: Editora 34, 2007. p. 251-276

ROLDAN, Sébastien. La pyramide des souffrances dans La joie de vivre d'Émile Zola. Québec: Université du Québec, 2012.

ROSSET, Clément. Prefácio. In: ROSSET, Clément. Lógica do pior. Rio de Janeiro: Espaço e Tempo, 1989. p. 7-9.

RUFFATO, Luiz. O brasileiro cordial. El País, Madrid, 3 jun. 2015. Disponível em: <http://brasil.elpais.com/brasil/2015/06/03/opinion/1433333585_575670.html>. Acesso em: 04 jun. 2015.

SANT'ANNA, André. O brasileiro é bom. In: SANT'ANNA, André. 0 Brasil é bom. São Paulo: Compa-nhia das Letras, 2014. p. 38-41

SARNEY, José. Carnaval neles. Folha de S. Paulo, São Paulo, 23 fev. 2001. Opinião, p. 2.

SCHWARCZ, Lilia K. Moritz. Um Brasil caricatural para alemão ver. Folha de S. Paulo, São Paulo, 6 nov. 1994. Mais!, p. 2.

TORRES, Bolívar. Revista francesa explica gafe com literatura brasileira. 0 Globo, Rio de Janeiro, 11 de dez. 2014. Disponível em: <http://oglobo.globo.com/cultura/livros/revistafrancesa-explica-gafe-com-literatura-brasileira-14802342\#ixzz3m35mUW19>. Acesso em: 13 dez. 2014.

VELASCO, Suzana. De mal com o bom humor. Revista 0 Globo, Rio de Janeiro, p. 20-27, 15 jun. 2014. 


\title{
Once upon a time there was "the land of joy": media, mood and national identity
}

\begin{abstract}
From the 1930s to the present time, the joie de vivre has been exalted as a vital component of Brazilianness, highly praised in nostalgic travelers' memoirs and in political and advertising rhetoric. It is a constitutive element of the identity, image and reputation of our nation. Writers and journalists contribute to create the stereotypical image of Brazil as the "land of joy". Now, under the impact of recent technological innovations, social transformations and political events, they are also helping to promote a reconsideration of our self-image. The aim of this article is to examine the changes that occur in the narratives about Brazilian character and culture. I emphasize, in particular, the public recognition of the presence of resentment in our history, social relations and political life.
\end{abstract}

\section{Keywords}

Joy. Resentment. Media. Stereotype. National identity.

Recebido em 19/09/2015

Aceito em 15/12/2015 